\title{
Measuring Brand Equity among Albanian Consumers
}

\author{
Rozana Haxhialushi, (Ph.C. Lecturer)
}

Department of Marketing-Tourism, Faculty of Economics,

University of Tirana, Albania

Vjollca Hysi Panajoti, (Prof. Dr.)

Head of Department of Marketing-Tourism, Faculty of Economics,

University of Tirana, Albania

Doi:10.19044/esj.2018.v14n16p106 URL:http://dx.doi.org/10.19044/esj.2018.v14n16p106

\begin{abstract}
Brands offer advantages for consumers and companies and companies are spending a lot in creating and managing their brands. Brand equity and its dimensions have received a great attention from academics. The purpose of this paper is to test the proposed model to better understand brand equity among Albanian consumers. It investigates the hierarchy of brand equity dimensions and the effect these dimensions have on brand equity. Hypothesis were tested using structural equation modeling. The reliability of the model was assessed using confirmatory factor analysis. Results show that brand awareness has a positive effect on brand associations, brand associations positively affect perceived quality which is positively related to brand loyalty. All dimensions have a positive effect on brand equity. Items for measuring overall brand equity were used. This study contributes to the large body of literature on brand equity. It has limitations because we use two product categories and a limited set of brands.
\end{abstract}

Keywords: Brand equity, brand awareness, brand associations, perceived quality, brand loyalty words

\section{Introduction}

Brands are the most valuable asset for a company after the customers (Doyle, 2001). According to Keller (2003) what consumers learn over time and their experiences with a brand constitute the power of the brand which actually exists in the customer's mind. When building a brand, managers try to link the brand image with a set of desirable associations so that the target group transfers them to the company's offered goods (del Rio, Vazquez, \& Iglesias, 2001; Johansson \& Carlson, 2015). 
Brands have an important role in everyday life and are at the focus of most marketing strategies. Over the last three decades, firms have increased their investments in the creation and development of brands. In the marketing literature, the term "brand equity", refers to the relationship between customers and brands (Wood, 2000). Kotler and Keller (2012) define a brand as a product or service whose dimensions differentiate it in some way from other products or services designed to satisfy the same need. These differences may be functional, rational, or tangible-related to product performance of the brand. They may be also more symbolic, emotional, or intangible-related to what the brand represents or means in a more abstract sense.

Positive consumer-based brand equity can lead to greater revenue, lower costs, and higher profits; and it has direct implications for the firm's ability to command higher prices, customer's willingness to seek out new distribution channels, the effectiveness of marketing communications, and the success of brand extensions and licensing opportunities (Keller, 2003). Brands provide advantages not only for companies but also for customers. Positive consumer-based brand equity can reduce functional risk and psychological risk, offer opportunities to express personality, and facilitate the decision making process (Johansson \& Carlson, 2015). Even though brand equity and it's dimensions are evaluated across countries, in Albania there are a few studies.

By re-testing the most popularly adopted brand equity dimensions, this study will examine the relationship between brand equity dimensions and brand equity in the case of a different country, product, methodology and sample profile.

This paper is organized as follows: it opens with a literature review. It describes the methodology, reports and discusses the empirical findings and their implications. Finally, it addresses the conclusions and limitations of the study.

\section{Literature review \\ Brand equity}

Brand equity is a multi-dimensional concept (Aaker, 1996; Yoo et al, 2000). Brand equity represents a valuable factor for interpreting marketing strategies and determining the brand's value and it can be used to increase and emphasize the brand's values in multiple distinct ways (Keller, 2009). Different researchers give different definitions of brand equity: as value added for the brand to a product (Farquhar, 1989); as the differentiator effect that the brand knowledge has on the consumer response to brand marketing (Keller, 1993). In 2003, Keller argues that the power of a brand lies in the minds of the customers and what they have experienced and learned about the brand over time. According to Aaker (1991) "brand equity is the joint of assets and 
responsibilities linked to the brand-name or symbol-that adds or subtracts value to the products of a company or to its customers". Brand awareness, brand associations, perceived quality, brand loyalty and other proprietary assets were the five assets of brand equity. Different authors (e.g. Aaker, 1991; Barwise, 1993) suggest that the identified dimensions can be used to investigate the findings of marketing and consumer behavior research in relation to brand equity. Yoo et.al. (2000) offered a more extended definition of brand equity acknowledging it for creating a blind preference of consumer for one brand opposite to its competitors, by increasing the value of the company affecting the margins and the decision processes in acquisition, by increasing responses in monetary market and allow the extensions of the brand". Brand equity comes primarily from a high level of customer affection and loyalty: it is "the depth" of brand allegiance (Johansson and Carlson, 2015, p.29).

The proposed model, as seen in Figure 1, investigates the effects of brand awareness, brand associations, perceived quality and brand loyalty on brand equity and the hierarchy of these dimensions. Buil et al. (2013) stated the necessity of understanding the brand equity creation process in different countries and cultures. Most researchers have given evidence of brand equity dimensions' hierarchy (Aaker, 1996; Yoo \& Donthu, 2001; Keller and Lehman, 2003); Yoo et al. (2000) and Pappu et al. (2005) propose associative relationship among brand equity dimensions, and Buil et al. (2013) have investigated how brand equity dimensions interrelate.

\section{Brand awareness}

This is the core level of brand equity: to make known that the brand exists. According to Aaker (1996) and Keller (2003), brand awareness is measured through brand recognition and recall. Knowing a brand's name isn't enough to create awareness. Consumers must know the identity and the functional risk that this brand promises to reduce (Johansson \& Carlson, 2015). Aaker (1991) defines brand awareness as the ability of the potential buyer to recognize and recall that a brand is a member of a category product whereas Kotler and Keller (2012) define it as the ability of the consumer to identify the brand under different conditions. As creating brand awareness is the first step to brand equity it must precede brand associations because awareness can affect costumer's perceptions, which lead to different brand choice and even loyalty (Aaker, 1991; 1996). There is a large body of empirical evidence that awareness is determinant to brand equity (Aaker, 1996; Keller, 2003; Mackay, 2001; Yoo \& Donthu, 2001; Pappu et al., 2005. So we hypothesize:

Hla: Brand awareness has a positive effect on brand equity.

HIb: Brand awareness has a positive effect on brand associations. 


\section{Brand Associations}

Aaker (1991, p.109) defines brand associations as "anything linked to the memory of the brand" and "represent the basis for purchase decisions, for brand loyalty and also create value to the firm and its customers". The associations are stronger when they depend on numerous encounters or exposures to communications, as opposed to rare (Aaker 1991). Brand associations' measures can be grouped in three different perspectives: the brand as a product, person and organization (Aaker, 1996; Chen, 2001; Keller, 2003; Netemeyer et al., 2004; Pappu et al., 2005). This associations are linked to trust and Lassar et al. (1995) and Martin and Brown (1990) have identified them as important elements of brand equity. Brand associations consist of multiple ideas, episodes, instances and facts that comprise a network of brand knowledge (Yoo et al., 2000). Managers use brand associations to position their brand in consumers mind to differentiate the product and to create positive attitudes toward brands (Low \& Lamb, 2000). So the following hypotheses are formulated:

$H 2 b$ : Brand associations have positive relationship in brand equity.

$H 2 b$ : Brand associations have a positive effect on perceived quality.

\section{Perceived quality}

Perceived quality is influenced by products features, performance, durability, serviceability and reliability, and is regarded as a core customerbased brand equity construct because of its association with the willingness to pay a price premium, intention to purchase a brand and choice of brand (Netemeyer et. al, 2004). Perceived quality is consumers' subjective judgement about a brand and exists in his mind. It is defined as the customer's perception of the overall quality or superiority of a product or service with respect to its intended purpose, relative to alternatives" (Zeithaml, 1988). Consumers use advertising as an extrinsic cue to judge the quality of products (Rao and Monroe, 1989). High perceived quality develops the perception of a brand as different from others (Aaker, 1996). So the following hypotheses can be postulated:

H3a: Perceived quality has a positive effect on brand equity.

H3b: Perceived quality has a positive effect on brand loyalty.

\section{Brand Loyalty}

Brand loyalty reflects the likeliness of chancing the brand due to a change in brand's price or product features (Aaker 1991). Loyal consumers show more favorable responses to a brand than non-loyal or switching consumers do (Grover \& Srinivasan, 1992). Perceived quality and brand associations represent the antecedent step leading to brand loyalty (Keller and Lehmann, 2003). Brand loyalty is the attachment or deep commitment to a 
brand (Aaker, 1991). When consumers acquire a more positive perception of a brand, loyalty results. Previous studies propose that high levels of perceived quality and positive associations can intensify brand loyalty (Chaudhuri, 1999; Keller and Lehmann, 2003). So the following hypotheses can be postulated: H4: Brand loyalty has a positive effect on brand equity.

Figure 1. The proposed model adapted from Aaker (1991)

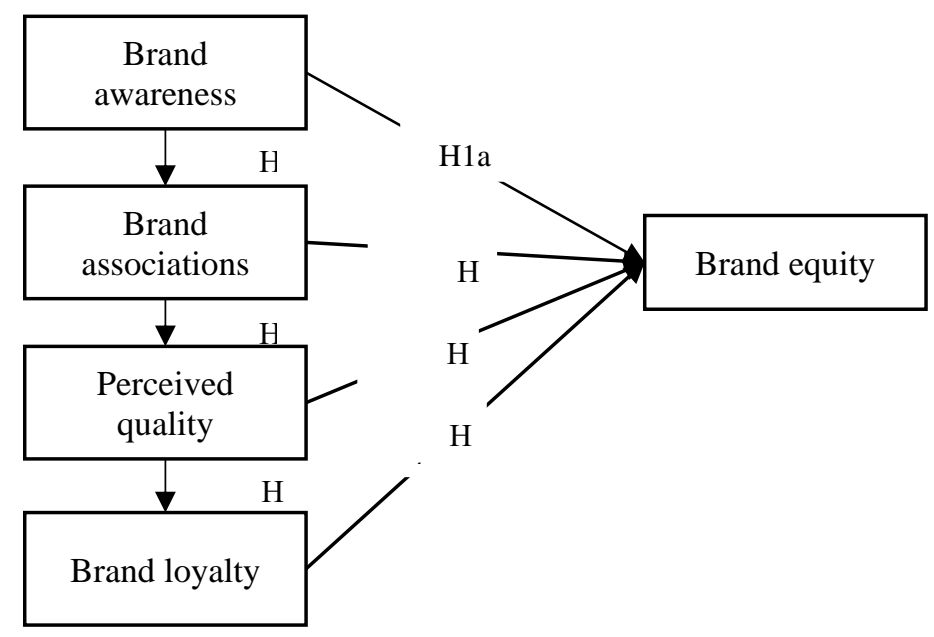

\section{Methodology}

\section{Procedure and sample}

In the study were included 7 brands of two product categories: 3 brands of athletic shoes (Adidas, Nike and Reebok) and 4 brands of energy drinks (Red Bull, B 52, Golden Eagle and Dragon Heart). We chose these brands because students might be familiar and can afford them. Seven versions of the questionnaire were prepared and handed out to 300 undergraduate students of the Faculty of Economics which were chosen randomly. Respondents were asked if they had ever bought the product category to be evaluated. If the answer was "Yes" they were handed the questionnaire. The questionnaire included demographics, brand awareness, brand attitude, perceived quality, brand loyalty and brand equity scales. Each respondent completed one version of the questionnaire and evaluated only one brand.

The questionnaire was administrated in Albanian and data were collected during March 2018. After discarding the questionnaires with missing data, 282 of them yielded eligible responses.

\section{Scale Development}

A literature review was undertaken to select the most appropriate way to measure each variable. The scale comprises five constructs whose items are 
well-established. The items for brand awareness, brand associations and brand loyalty were adapted from Aaker (1991, 1996), Yoo et al. (2000), and Netemeyer et al. (2004). The items for measuring perceived quality were adapted from Pappu et al. (2005). Yoo et al. (2000) have developed the overall brand equity scale and four items from this scale were adopted to measure the consumer-based brand equity. A five-point Likert scale will be used, ranging from " $1=$ strongly disagree to " $5=$ strongly agree".

\section{Analysis of results and Discussion Sample demographics}

The major proportionate of the respondents were female, 220 of the total number of the respondents, around $78 \%$, and 62 were male students, approximately $22 \%$. As they were undergraduate students the average age was 22. The marital status of the respondents indicates that $39 \%$ were single, $56 \%$ were in a relationship and $5 \%$ were married. $15 \%$ had family income less than $200 €, 20 \%$ had family income $200 €-500 €, 39 \%$ had family income $500 €$ $800 €$, and $26 \%$ had family income above $800 €$.

\section{Measurement model}

In order to validate the measurement scale of brand equity confirmatory factor analysis was conducted (Hair et al, 2010). 22 measurement items and five constructs were subjected to confirmatory factor analysis using AMOS 16 for assessing psychometric properties. To quantify the model fit, adequate indexes were calculated: the goodness-of-fit index $\mathrm{GFI}=0.920$, adjusted goodness-of-fit index $\mathrm{AGFI}=0.916$, the normed fit index $\mathrm{NFI}=0868$, Tucker-Lewis Index TLI=0.921, incremental fit index $\mathrm{IFI}=0.899$, the relative fit index $\mathrm{RFI}=0.789$, comparative fit index $\mathrm{CFI}=0.912$ and root mean square error of approximation RMSEA=0.038. According to Hair et al. (2010) the indexes of GFI, AGFI, CFI and TLI should be greater than 0.9, whereas the values of NFI, RFI AND IFI should be large enough in the 0-1 interval. All the indexes evaluated for our model exceeded the recommended benchmark. The value of RMSEA should be smaller than 0.08 , in our model is 0.038 . The chi square of the model was $\chi^{2}(210)=233.79 ; \chi^{2} / \mathrm{df}=1.82$ and shows a good fit.

Reliability and validity of measured items were established. For examining convergent validity we estimate each indicator's maximum likelihood loading. Hair et al. (2010) suggests all standardized loading should be at least 0.5 , preferably 0.7 and higher. Results of Table 1 show that all the loadings are above 0.70 and this provides evidence of convergent validity. To assess the internal reliability of the measures, composite reliability and average variance extracted for all scales were used. 
Composite reliability (CR) were above the benchmark of 0.70 so they are considered adequate (Hair et al, 2010). AVE's are above the threshold of 0.5 so they are indications of convergent validity (Anderson and Gerbing, 1988). Table 1 presents the loadings of each item on its respective latent construct.

The factor loading, construct reliability and the average variance extracted measurements, for all dimensions of brand equity are significant and fall in the satisfactory limit. It can be concluded that all the measurement items of constructs were consistent and there were less chances of occurrences of error.

Table 1. Results for the measurement model

\begin{tabular}{|c|c|c|c|c|c|c|}
\hline Constructs & items & item loading & Mean & St.Dev & AVE & $\mathrm{CR}$ \\
\hline \multirow{6}{*}{ Brand awareness } & AW1 & 0.863 & 3.5 & 0.734 & 0.693 & 0.929 \\
\hline & AW2 & 0.810 & & & & \\
\hline & AW3 & 0.786 & & & & \\
\hline & AW4 & 0.822 & & & & \\
\hline & AW5 & 0.860 & & & & \\
\hline & AW6 & 0.835 & & & & \\
\hline \multirow{5}{*}{ Brand associations } & BA1 & 0.801 & 4.0 & 0.656 & 0.662 & 0.901 \\
\hline & BA2 & 0.708 & & & & \\
\hline & BA3 & 0.767 & & & & \\
\hline & BA4 & 0.850 & & & & \\
\hline & BA5 & 0.891 & & & & \\
\hline \multirow{4}{*}{ Perceived quality } & PQ1 & 0.884 & 3.8 & 0.764 & 0.658 & 0.884 \\
\hline & $\mathrm{PQ} 2$ & 0.766 & & & & \\
\hline & PQ3 & 0.761 & & & & \\
\hline & PQ4 & 0.829 & & & & \\
\hline \multirow{3}{*}{ Brand Loyalty } & BL1 & 0.878 & 4.2 & 0.565 & 0.747 & 0.898 \\
\hline & BL2 & 0.860 & & & & \\
\hline & BL3 & 0.857 & & & & \\
\hline \multirow{4}{*}{ Brand equity } & OBE1 & 0.863 & 4.3 & 0.672 & 0.743 & 0.920 \\
\hline & OBE2 & 0.857 & & & & \\
\hline & OBE3 & 0.837 & & & & \\
\hline & OBE4 & 0.880 & & & & \\
\hline
\end{tabular}

To be sure that discriminant validity is attained we check the correlations between constructs, to see if they are different from 1, or when chi-square difference tests indicate that two constructs are not perfectly correlated. As a test of discriminant validity, the correlations among the latent variables were checked to determine if they are significantly different from 1 (Table 2). AVE for any two constructs was greater than the square of the correlation estimate. Table 3 shows that the inter-correlations between brand equity dimensions are significant at the 0.05 level and are positively correlated. Brand loyalty has the strongest correlation with brand equity 
(0.82), followed by brand awareness (0.78), brand associations (0.76) and perceived quality $(0.71)$.

Table 2. Correlation matrix

\begin{tabular}{|cccccc|}
\hline & AW & BA & PQ & BL & OBE \\
AW & 1.00 & & & & \\
BA & 0.79 & 1.00 & & & \\
PQ & 0.77 & 0.81 & 1.00 & & \\
BL & 0.79 & 0.78 & 0.80 & 1.00 & \\
OBE & 0.78 & 0.76 & 0.71 & 0.82 & 1.00 \\
\hline
\end{tabular}

Notes: All coefficients are significant at $\mathrm{p}<0.05$

$A W$-brand awareness, BA-brand association, $P Q$-perceived quality, BL-brand loyalty, OBEoverall brand equity.

\section{Structural model}

Structural equation modeling was used to estimate the parameters of the structural model, and completely standardized solution was computed by AMOS 16. The structural model specified brand equity dimensions (brand awareness, brand association, perceived quality, and brand loyalty) to be hierarchal and related to brand equity. Goodness-of-fit statistics, indicating the overall acceptability of structural model analyzed, showed good fit with the data: $\chi^{2}(\mathrm{df})=374.19(19) ; \chi^{2} / \mathrm{df}=19.69 ; \mathrm{CFI}=0.96$; IFI $=0.96$; $\mathrm{RMSEA}=$ $0.14 ; \mathrm{GFI}=0.94$.

The hypothesized paths were significant. A detailed result of the path analyses is reported in Table 3. As hypothesized, brand awareness (H1a), brand association ( $\mathrm{H} 2 \mathrm{a})$, perceived quality ( $\mathrm{H} 3 \mathrm{a})$ and brand loyalty $(\mathrm{H} 4)$ emerged as significant dimensions of brand equity. Brand equity was positively related to brand awareness, brand association, perceived quality and brand loyalty. The relationship of brand loyalty $(\beta=0.68, \mathrm{p}<0.05)$ to brand equity was stronger than the relationships of brand awareness $(\beta=0.51$, $\mathrm{p}<0.05)$, perceived quality $(\beta=0.44, \mathrm{p}<0.05)$ and brand association $(\beta=0.28$, $\mathrm{p}<0.05)$ to brand equity.

The hypothesis for hierarchichal relationship among brand equity dimensions, H1b, H2b and H3b, were supported. Empirical support was found for the relationships between brand awareness and brand association $(\beta=0.24$, $\mathrm{p}<0.01)$, brand association and perceived quality $(\beta=0.34, \mathrm{p}<0.01)$, perceived quality and brand loyalty $(\beta=0.41, \mathrm{p}<0.01)$. 
Table 3. Results of the structural model

\begin{tabular}{ccccc}
\hline Hypothesis & Hypothesised relationship & Std.coefficient & $t$ & Decision \\
\hline H1a & Brand awareness $\rightarrow$ Brand equity & $0.51^{*}$ & 13.75 & Supported \\
H1b & Brand awareness $\rightarrow$ Brand associations & $0.24^{*}$ & 11.54 & Supported \\
H2a & Brand associations $\rightarrow$ Brand equity & $0.28^{*}$ & 17.53 & Supported \\
H2b & Brand associations $\rightarrow$ Perceived quality & $0.34^{*}$ & 11.38 & Supported \\
H3a & Perceived quality $\rightarrow$ Brand equity & $0.44^{*}$ & 9.36 & Supported \\
H3b & Perceived quality $\rightarrow$ Brand loyalty & $0.41^{*}$ & 15.24 & Supported \\
H4 & Brand loyalty $\rightarrow$ Brand equity & $0.68^{*}$ & 24.65 & Supported \\
\hline
\end{tabular}

Note: $* p<0.05$

\section{Conclusion}

The present study explores the hierarchy between brand equity dimensions and the relationship between brand equity and its dimensions. To measure brand equity construct we employed the scale proposed by Yoo et al. (2000). For the other dimensions, well-established multiple item constructs were used, adopted by previous studies.

Results indicate that all four dimensions of brand equity proposed by Aaker (1991) have a significant positive relationship with overall brand equity. Brand loyalty is the most significant driver of brand equity followed by brand awareness, brand associations and perceived quality. Results are in conform to prior research findings (Yoo et al., 2000; Atilgan et al., 2005; Wang et al., 2006; Buil et al, 2013). The results indicate that a hierarchy order exist among the constructs. First, brand awareness has a positive effect on brand associations. Perceived quality is positively influenced by brand associations and finally, brand loyalty is influenced by perceived quality.

The empirical findings offer academic contributions to the existing body of knowledge of consumer behavior. Also the findings, provide evidence of the benefits companies can have from developing high brand equity among consumers. Brands that have high equity are well-known to the targeted segment, have positive and favorable associations, are considered of good quality and have loyal customers, who won't abandon the brand even in the worst days (Johansson \& Carlson, 2015).

\section{Limitations of the study}

This empirical study has several limitations. First, research was conducted among 282 students so the used sample is narrow to generalize the whole population of Albania. Only two product categories were used. At last, the findings of this study depend on the honesty of the respondents to give the true answer. 


\section{References:}

1. Aaker, A. (1991). Managing Brand Equity: Capitalizing on the value of brand name. New York: The Free Press.

2. Aaker, A. (1996). "Measuring brand equity across products and markets". California Management Review, 38(3), 102-120.

3. Anderson, J. C., \& Gerbing, D. W. (1988). "Structural equation modeling in practice: a review and recommended two-step approach". Psychological Bulletin, 103(3), 411-423.

4. Atilgan, E., Aksoy, S., \& Akinci, S. (2005). "Determinants of brand equity: A verification approach in the baverage industry in Turkey". Marketing Intelligence and Planning, 23(3), 237-248.

5. Barwise, P. (1993, March). "Brand equity: Snark or Boojum?". International Journal of Research in Marketing, 10(1), 93-104.

6. Buil, I., Martinez, E., \& de Chernatony, L. (2013). "The influence of brand equity on consumer responses". Journal of Consumer Marketing, 30(1), 62-74.

7. Chaudhuri, A. (1999). "Does brand loyalty mediate brand equity outcomes?". Journal of Marketing Theory and Practice, 7(2), 136-146.

8. Cobb-Walgren, C. J., Ruble, C. A., \& Donthu, N. (1995). "Brand equity, brand preference and purchase intend". Journal of Advertising, 24(3), 25-41.

9. del Rio, A. B., Vazquez, R., \& Iglesias, V. (2001). "The effects of brand associations on consumer response". Journal of Consumer Marketing, 18(5), 410-425.

10. Doyle, P. (2001). "Shareholder-value-based brand strategies". Journal of Brand Management, 9(1), 20-30.

11. Farquar, P. (1989). "Managing brand equity". Marketing Research, 48, 24-33.

12. Hair, J. F., Jr, Anderson, R. E., Babin, B. E., \& Black, W. C. (2010). Multivariate data analysis (7th edition ed.). New Jersey: Prentice-Hall.

13. Johansson, J. K., \& Carlson, K. A. (2015). Contemporary Brand Management. Los Angelos: Sage.

14. Keller, K. L. (1993). "Conceptualizing, measuring, managing customer-based brand equity". Journal of Marketing, 57(1), 1-22.

15. Keller, K. L. (2009). "Building strong brands in a modern marketing communication". Journal of Marketing Communication, 12(2-3), 139155.

16. Keller, K. L. (2003). Strategic Brand Management: Building, Measuring and Managing Brand Equity (2nd ed.). New York: Prentice-Hall,Englewood Cliffs.

17. Keller, K. L., \& Lehmann, D. R. (2003). "How do brands create value?". Marketing Management, 12(3), 26-31. 
18. Kotler, P., \& Keller, K. L. (2012). A framework for marketing management (5th ed.). Boston: Prentice-Hall.

19. Lassar, W., Mittal, B., \& Sharma, A. (1995). "Measuring customerbased brand equity". Journal of Consumer Marketing, 12(4), 11-20.

20. Low, G., \& Lamb, C. J. (2000). "The measurement and dimensionality of brand associations". Journal of Product and Brand Management, 9(6), 350-370.

21. MacKay, M. (2001). "Evaluation of brand equity measures:further empirical evidence". Journal of product and brand management, $10(1), 38-51$.

22. Martin, G. S., \& Brown, T. J. (1990). "In search of brand equity: the conceptualization and measurement of the brand impression construct". Marketing Theory and Applications, 2, 431-438.

23. Netemeyer, R., Krishnan, B., Pulling, C., Wang, G., Yagci, M., Dean, D., ... Wirth, F. (2004). "Developing and validating measures of facets of consumer-based brand equity". Journal of Business Research, 57, 209-224.

24. Pappu, R., Quester, P. G., \& Cooksey, R. W. (2005). "Consumer-based brand equity: improving the measurement-empirical evidence". Journal of Product and Brand Management, 14(3), 143-154.

25. Rao, A. R., \& Monroe, K. B. (1989). "The effect of price, brand name and store name on buyers' perception of product quaility: an integrative review". Journal of Marketing Research, 36(2), 351-358.

26. Washburn, J. H., \& Plank, R. E. (2002). "Measuring Brand Equity: An evaluation of a consumer-based brand equity scale". Journal of Marketing Theory and Practice, 10(1), 46-62.

27. Wang, Y., Kandampully, J.A., Lo, H. and Shi, G. (2006). “The roles of brand equity and corporate reputation in CRM: a Chinese study", Corporate Reputation Review, 9(3), 179-97.

28. Wood, L. (2000). "Brands and brand equity: definition and management". Management Decision, 38(9), 662-669.

29. Yoo, B., \& Donthu, N. (2001). "Developing and validating a multidimensional consumer-based brand equity scale". Journal of Business Research, 52, 1-14.

30. Yoo, B., Donthu, N., \& Lee, S. (2000). "An examination of selected marketing mix elements and brand equity". Journal of the Academy of Marketing Science, 28(2), 195-211. doi:10.1177/0092070300282002

31. Zeithaml, V. (1988). "Consumer perceptions of price, quality and value: a means-end model and synthesis of evidence". Journal of Marketing, 52(3), 2-22. 